\title{
Teaching English through Principles of Instructed Language Learning
}

\author{
Luu Hoang Mai \\ Saigon Technology University (STU), Ho Chi Minh City; \\ University of Social Sciences \& Humanities, Ho Chi Minh City, Vietnam \\ Luu Thi Bich Ngoc \\ Open University, Ho Chi Minh City, Vietnam \\ Luu Trong Tuan \\ University of Finance-Marketing, Ho Chi Minh City, Vietnam
}

\begin{abstract}
Teaching is an interesting profession with new approaches expanding teachers' roles and giving teachers more insights into how to help their learners (Larsen-Freeman, 1988). This paper serves as a reflection on our teaching English to first-year EFL students at Saigon Technology University which demonstrates how Ellis's (2005) principles of Instructed Language Learning were applied in Vietnam context.
\end{abstract}

Index Terms — instructed language learning, second language acquisition, learning style, teaching strategy

\section{INTRODUCTION}

Ellis (2005, p. 209) draws together "findings from a range of second language acquisition studies" and formulates 10 general principles of instructed language learning. "They are:

1. Instruction needs to ensure that learners develop both a rich repertoire of formulaic expressions and a rule-based competence.

2. Instruction needs to ensure that learners focus predominantly on meaning.

3. Instruction needs to ensure that learners also focus on form.

4. Instruction needs to be predominantly directed at developing implicit knowledge of the L2 while not neglecting explicit knowledge.

5. Instruction needs to take into account the learner's built-in syllabus.

6. Successful instructed language learning requires extensive L2 input.

7. Successful instructed language learning also requires opportunities for output.

8. The opportunity to interact in the L2 is central to developing L2 proficiency.

9. Instruction needs to take account of individual differences in learners.

10. In assessing learner's L2 proficiency it is important to examine free as well as controlled production."

These principles neatly sum up the current understanding of L2 acquisition theories and practices. Even though Ellis (2005, p. 210) called these principles "provisional speculations", they have been attested in L2 classroom research and practice. The following reflection on our teaching English to first-year EFL students at Saigon Technology University demonstrates how these principles of Instructed Language Learning were applied in Vietnam context.

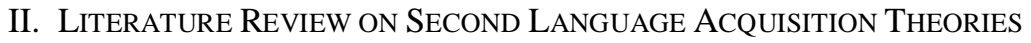

\section{Nativist Theory or Naturalistic Approach}

According to Brown (1973), the term nativist "is derived from the fundamental assertion that language acquisition is innately determined, that we are born with a built-in device of some kind that predisposes us to language acquisition." Chomsky (1965) proposed the theory that all people have an innate, biological ability to acquire a language or possess a Language Acquisition Device (LAD), a sort of neurological wiring that, regardless of the language to be acquired, allows a child to listen to a language, decipher the rules of that language, and begin creating with the language at a very young age. According to Chomsky, LAD 'governs all human languages, and determines what possible form human language may take' (Dulay, Burt, and Krashen, 1982, p. 6ff).

Krashen (1981) developed his Monitor Theory based on Chomsky's concept of a LAD. The Monitor Theory is composed of four hypotheses: The Input Hypothesis; The Natural Order Hypothesis; The Affective Filter Hypothesis; and The Acquisition vs. Learning Hypothesis. These hypotheses provide the framework for the communication-based teaching strategies.

Environmentalist Theory 
Environmentalists posit that environmental/outside influences over the learner play a substantial role in acquisition of a second language. The principal environmentalist theory, Schumann's “Acculturation Model," suggests that a learner's social and psychological distance from the target language group influences that individual's ability to develop proficiency in the target language.

Schumann (1978) describes psychological distance consisting of three factors: 1) culture shock, 2) language shock, and 3) motivation. Social distance refers to the social proximity of two cultures that come into contact with one other. Schumann (1978) describes social distance comprising "eight social variables which affect the quality of contact that second language learners have with the target language community:

1) Social dominance: When the English Language Learning (ELL) group is politically, culturally, technically, or economically superior to the target language (TL) group, then it will tend not to learn the target language. On the other hand, if the ELL group is inferior to the TL group, they may resist learning the target language.

2) Assimilation, preservation, and adaptation: If the ELL group chooses assimilation as the integration strategy, it gives up its own lifestyle and values and adopts those of the TL group. Similarly, preservation means that the ELL group maintains its own lifestyle and values and rejects those of the TL group. Adaptation means that the ELL group adapts to the lifestyle and values of the TL group, but maintains its own lifestyle and values for intragroup use.

3) Enclosure: Enclosure refers to the degree to which the ELL group and TL group share the same social constructs such as schools, churches, clubs, recreational facilities, crafts, professions, and trades. If the two groups share these social constructs, enclosure is said to be low, and the L2 acquisition is facilitated.

4) Cohesiveness: If the ELL group is cohesive, it will tend to remain separate from the TL group.

5) Size: If the ELL group is large, the intragroup contact will be more frequent than contact with the TL group.

6) Congruence: If the two cultures are similar, social contact is potentially more likely and L2 learning is more easily facilitated.

7) Attitude: If the ELL and TL groups have positive attitudes toward each other, L2 learning is more easily facilitated.

8) Intended length of residence: The longer an L2 learner plans to remain in the TL environment, the more likely it is that they will feel the need to learn the target language."

\section{Cognitive Approach}

Cognitive psychologists claim that one of the main features of second language acquisition is the building up of a knowledge system that can eventually be called on automatically for understanding.

McLaughlin's Attention-Processing Model

This model connects processing mechanisms with categories of attention to formal properties of language. Consequently there are four cells. The first one refers to 'focal automatic processes' like the student's performance in a test situation or a violin player performing in a concert. The second one characterizes 'focal controlled processes' such as the learner's performance based on formal rule learning. The next cell refers to 'peripheral controlled processes' such as the phenomenon of learning skills without any instruction. The last cell focuses on 'peripheral automatic processes' and can be related to a learner's performance in situations of communication. "Controlled processes are "capacity limited and temporary", and automatic processes are "relatively permanent"' (McLaughlin et al. 1983, p. 142 in Brown, 2002).

Implicit and Explicit Models

According to Brown and other linguists, there is a distinction between implicit and explicit linguistic knowledge. Explicit knowledge means 'that a person knows about language and the ability to articulate those facts in some way' (Brown, 2002, p. 285). Implicit knowledge is 'information that is automatically and spontaneously used in language tasks. [...] Implicit processes enable a learner to perform language but not necessarily to cite rules governing the performance' (Brown, 2002, p. 285).

\section{IMPLEMENTATION OF PRINCIPLES OF INSTRUCTED LANGUAGE LEARNING}

\section{Principle 1: Instruction needs to ensure that learners develop both a rich repertoire of formulaic expressions and a rule-based competence}

A notional-functional approach lends itself perfectly to the teaching of prefabricated patterns and routines and may provide an ideal foundation for direct intervention in the early stages. Conspicuously, though, a complete language curriculum needs to ensure that it caters to the development of both formulaic expressions and rule-based knowledge (Ellis, 2005).

Formulaic expressions were utilized throughout our English lessons. Our students had access to formulaic expressions in the ensuing ways:

1. Expressions were written on the blackboard. Our teaching Unit 1A "Let's get to know each other" of the coursebook "Let's Talk" (Jones, 2008, pp. 4-5) covered such examples of formulaic expressions as: What's your last name? Where are you from? Where do you live? Where do you work? and What are your hobbies?. The students were continually encouraged to use these expressions to communicate with one another in class.

2. The students had sheets of expressions handed out to them at the beginning of class.

These formulaic expressions also arose out of interactions with framework goals. That is, they consisted of instructional language, in which I endeavoured to explain the procedures for performing an activity or to monitor the 
students' understanding. These expressions from Unit 11A "How to get there" of the coursebook "Let's Talk" encompassed "Go/Walk up Second Avernue", "Turn left/right", "Go past the drugstore", and so forth (Jones, 2008, pp. 48-49).

The students also used numerous formulaic chunks in English. The phrases they used during the lessons embraced: "Thank you very much", "You are welcome", "My name is X", etc.

Teaching formulaic expressions was indispensible since formulaic expressions relating to framework goals could be useful if the students went to and studied in an English-speaking country. Furthermore, one of the biggest advantages of learning these formulaic expressions was that the students could develop listening skills, especially getting accustomed to sounds of English through exposure to these expressions. Instruction also focused on developing the students' ability to apply grammatical rules.

\section{Principle 2: Instruction needs to ensure that learners focus predominantly on meaning}

The term 'focus on meaning' is somewhat ambiguous. It is essential to distinguish two different senses of this term. The first refers to the idea of semantic meaning (i.e. the meanings of lexical items or of specific grammatical structures). The second sense of focus on meaning relates to pragmatic meaning (i.e. the highly contextualized meanings that arise in acts of communication). To provide opportunities for students to attend to and perform pragmatic meaning, a taskbased (or, at least, a task-supported) approach to language teaching is needed (Ellis, 2005).

Our lessons focused predominantly on semantic rather than pragmatic meaning. For instance, in Unit 7A "Eating out" of the coursebook "Let's Talk" (Jones, 2008, pp. 30-31), the students learnt the names of different foods such as beef curry, fruit salad, onion soup, and spaghetti, listened to a taped dialogue where they had to identify what a family had for a particular meal, and participated in a role play where they had to decline or accept food (as depicted on cards that they turned over) according to given instructions. Occasions where they had to focus on pragmatic meaning were when they were required to follow instructions given to them in English by the teacher such as discussion in groups on how to make a birthday cake or on what foods they prepare for their family reunion on the weekend.

\section{Principle 3: Instruction needs to ensure that learners also focus on form}

Learners need to pay attention to specific forms in the language they are learning. In the context of attempting to communicate accurately, learners discover the magnitude of focusing on the form of the language that they use. Teachers can help them by giving them focused tasks rather than teaching grammar in isolation. However, "focus on form" and "focus on forms" have different connotations in the literature.

Focus on form

Focus on form is the term used to depict the cognitive processes by which learners attend to form incidentally when comprehending or producing communicative messages. Long (1991) uses the term to refer to instruction that engages learners' attention to form while they are primarily focused on message content.

Focus on forms

Long (1991) uses this term to refer to instruction directed at teaching pre-selected linguistic items in activities where the students' primary focus of attention is on form rather than meaning.

Instruction can seek to provide an intensive focus on pre-selected linguistic forms (as in a focus-on-forms approach or in a lesson built around a focused task) or it can offer incidental and extensive attention to form through corrective feedback in task-based lessons (Ellis, 2005).

Opportunities to focus on form were provided for students in all our lessons. These opportunities were through grammar lessons designed to teach specific features; therefore the focus on form was both planned and intensive. The students were given explicit information about target-language structures, which included grammatical rules and the use of metalinguistic terms.

For instance, in our lesson on Unit 6A "How was your trip?" of the coursebook "Let's Talk" (Jones, 2008, pp. 26-27), I asked students to summarise the use of the simple past tense and the pronunciation of irregular verb past forms and the suffix "-ed" in regular verb past forms. The students then worked on activities that gave them structured practice of verb past forms, which provided occasions for teacher-initiated corrective feedback.

There were also examples of incidental and extensive focus on form. For instance, in discussing Your interests in Unit 3A "What are your interests" and Unit 3B "What sports do you like?" of the coursebook "Let's Talk" (Jones, 2008, pp. 12-15), I drew the students' attention to the difference in the use of indefinite article between "play a sport" (eg. play tennis) and "play a musical instrument" (eg. play the guitare). Correction of students' errors was at times occasion for a brief period of "time out" to focus on form in the lesson. In our lesson on Unit 8B "What's on TV tonight?" of the coursebook "Let's Talk" (Jones, 2008, pp. 36-37), I explicated, in response to the error "I see TV", that students had to use the verb watch instead of see with the noun TV.

Principle 4: Instruction needs to be predominantly directed at developing implicit knowledge of the target language while not neglecting explicit knowledge

In Ellis's (2005) standpoint, explicit knowledge is held consciously, is learnable and verbalisable, and is typically accessed through controlled processing when learners experience some kind of linguistic difficulty in using the L2. In contrast, implicit knowledge is procedural, is held unconsciously, and can only be verbalized if it is made explicit. It is accessed briskly and easily and thus is available for use in rapid, fluent communication. 
Focus on developing students' explicit knowledge was addressed in our teaching. In Unit 15A "Childhood memories" of the coursebook "Let's Talk" (Jones, 2008, pp. 66-67), for example, where the focus was the use of verb past forms, the students were asked to explain differences in pronunciation of verb ending "-ed". On a number of occasions, irregular verbs such as feel and hide were conjugated on the board for students.

There were also opportunities, however, for students in the lessons to "proceduralise" explicit knowledge (that is, develop implicit knowledge through practice - DeKeyser, 1998). Students were given repeated practice in orally naming pictured activities, which required the use of verb past forms. In another lesson, students were given opportunities to practise verb past forms in response to questions posed by the teacher (What games did you play as a child? What did you like about your childhood? What didn't you like?) and in structured pair work.

I also used implicit feedback to involve students in error correction process. Implicit feedback occurs when the corrective force of the response to learner error is masked, for example, a recast, which reformulates a deviant utterance correcting it while keeping the same meaning:

Student: Why Howard felt sad?

I - the teacher: $\quad$ Why did Howard feel sad?

Student: Yeah, Why did Howard feel sad?

Principle 5: Instruction needs to take into account the learner's “built-in syllabus"

Research has shown that there is a consistent process for acquiring language. Initial research revealed that second language learners who had no formal instruction mastered the use of grammatical structures in a fairly consistent order, going through similar learning stages for each structure. This could be called the "natural" developmental process; it is also known as the "built-in syllabus".

Researchers concluded that teachers could best help learners by providing explicit instruction that was compatible with the "natural" developmental process and that built on that process.

Nouns on clothing were the specific grammatical focus of Unit 5A "Shopping and clothing" of the coursebook "Let's Talk" (Jones, 2008, p. 22). In introducing this grammar point to the students, I provided a listening task without planning the grammatical content of the lesson. Students would hear the word "jeans" in plural form. From this knowledge base the students have just developed, I then focused on making key information about grammar point on plurality of the noun of clothing which consists of two integral functional parts. Based on this "natural" developmental process or "built-in syllabus", the students can use similar nouns in plural forms such as shorts and pants.

Principle 6: Successful instructed language learning requires extensive target-language input

If learners do not receive exposure to the target language, they can not acquire it. By and large, the more exposure they receive, the more and the faster they will learn (Ellis, 2005). Our teaching, therefore, endeavoured to turn all lessons into occasions for students to gain extensive input in English.

Language goals

The lessons aimed for more than 70\% interactions in English. The students discussed with the teacher in English. I explained to the students how language activities were to be conducted in English, for example, Work in pairs. One of you should look at Task 2 on page 76, and the other at Task 19 on page 84; Interview your partner and take notes; Complete the chart with a partner; Label the pictures with the words in the box.

Social goals

Before the lesson began, individual students were greeted in English and there was some discussion on how they were.

Framework goals (classroom management)

Again, in almost all lessons, the target language was used for these goals. The students were given instructions in English, for instance, Who is missing today? Can you get me some pieces of chalk? Close your books! Write it down on the board! Quiet please!

Principle 7: Successful instructed language learning also requires opportunities for output

Contrary to Krashen's insistence that acquisition is contingent entirely on comprehensible input, most researchers now acknowledge that learner output also plays a part (Ellis, 2005).

There were numerous opportunities for the students to produce target-language output in all our class meetings. I frequently told students that yes/no answers were insufficient. They were encouraged to use phrases such as I agree/I don't agree/ I disagree/ I share your point. Students tended to speak in full clauses and, from time to time, in multipleclause sentences. Our lesson on Unit 8A “Let's see a movie!" of the coursebook "Let's Talk" (Jones, 2008, pp. 34-35) demonstrated examples of this kind:

I saw Transformer 3 last month, but I didn't like it very much. It was too violent.

I think Kungfu Panda looks exciting and educational.

Cars 2 is playing today.

The students were involved in text creation as well as text manipulation in that they had to use their own linguistic resources to answer questions requiring them to give explanations, make comparisons, express an opinion, and so forth. Our lessons also provided students with 'auto-input' (i.e. learners can attend to the 'input' provided by their own productions) (Ellis, 2003) for instance: 
I think Kungfu Panda looks exciting and educational. Yes, it is educational since it reminds us of inner peace needed for effective actions. We students need inner peace when we study English.

Principle 8: The opportunity to interact in the target language is central to developing proficiency

While it is useful to consider the relative contributions of input and output to acquisition, it is also crucial to acknowledge that both co-occur in oral interaction and that both computational and sociocultural theories of L2 acquisition have viewed social interaction as the matrix in which acquisition takes place (Ellis, 2005).

Almost all student interactions with I - the teacher was in the target language. As has been depicted elsewhere, lesson objectives were negotiated in discussion with the teacher, tasks were discussed, awarding of points was negotiated, and the lesson was appraised. The right and need to speak in English had to be negotiated by both the teacher and the students.

There were numerous instances of our - the teacher's - scaffolding the students' attempts to use the target language. The following are given as examples.

1. The teacher cued students as to the word that they needed, for instance,

I (Teacher): I like to ride on roller ... (Look at the picture), roller coasters.

2. The teacher cued students as to the appropriate response to a question.

I (Teacher): What kind of music do you like? I like ...

Student: $\quad$ I like ... pop music.

On other occasions, I gave students a choice of linguistic structures appropriate to a particular context.

I (Teacher): You like or you don't like pop music?

Student: $\quad$ I like pop music.

There were a number of occasions where students worked in groups. Interactions between students occurred in the target language.

It is also crucial to give students a choice about the topics that they focused on in class and that it was very motivating for them when they were involved in negotiating these. I also endeavoured to set up opportunities for students to interact with native speakers. I from time to time invited a native English speaker who was our colleague at an evening English center to attend our class for our students to interact with him.

Principle 9: Instruction needs to take account of individual differences in learners

The values of learner diversity are acknowledged by Sarasin (1999) that: "We improve our courses because our classes benefit from the diversity of our students, [...]" whereas most Asian teachers 'ignore' learners' ways (Renandya et al., 2001). Therefore, prior to teaching this class, I conducted a questionnaire survey to explore the distribution of learning styles among the students. The questionnaire comprising 44 closed-ended questions suggested by Solomon and Felder (1999) was reproduced in Vietnamese and delivered to the students. The distribution of learning styles among these students is displayed in Table 1.

TABLE 1:

LEARNING STYLE DISTRIBUTION $(\mathrm{N}=38)$

\begin{tabular}{|l|l|l|l|}
\hline \multicolumn{2}{|l|}{ Dimensions of learning styles } & $\mathrm{n}$ & $\%$ \\
\hline Perception & Sensing & 15 & 39.47 \\
& Intuitive & 23 & 60.53 \\
\hline Input & Visual & 26 & 68.42 \\
& Verbal & 12 & 31.58 \\
\hline Processing & Active & 22 & 57.89 \\
& Reflective & 16 & 42.11 \\
\hline Understanding & Sequential & 28 & 73.68 \\
& Global & 10 & 26.32 \\
\hline
\end{tabular}

Teaching strategies involve choice of tasks, forms of answer, forms of interaction, and references appealing to the range of learning styles of the class (Table 2). 
TABLE 2:

TEACHING STRATEGIES TO MATCH DIFFERENT LEARNING STYLES

\begin{tabular}{|c|c|c|c|c|c|}
\hline Learning styles & $\begin{array}{l}\text { Teaching } \\
\text { strategies }\end{array}$ & Tasks & Forms of answer & $\begin{array}{l}\text { Forms of } \\
\text { interaction }\end{array}$ & References \\
\hline Sensing & $\begin{array}{l}\text { images, sounds, } \\
\text { video, demos }\end{array}$ & creations of demos, images & $\begin{array}{l}\text { quizzes with } \\
\text { accompanying images, } \\
\text { audio }\end{array}$ & $\begin{array}{l}\text { pair work, } \\
\text { group work }\end{array}$ & $\begin{array}{l}\text { video or audio clips from a } \\
\text { media collection }\end{array}$ \\
\hline Intuitive & $\begin{array}{l}\text { settling and } \\
\text { prediction }\end{array}$ & problem solving & $\begin{array}{l}\text { essays that ask for } \\
\text { outcome projections }\end{array}$ & group work & $\begin{array}{l}\text { readings from various view } \\
\text { points }\end{array}$ \\
\hline Visual & $\begin{array}{l}\text { use of a video } \\
\text { clip, diagram, } \\
\text { image or map }\end{array}$ & $\begin{array}{l}\text { mind mapping of concepts } \\
\text { (webbing), diagramming }\end{array}$ & $\begin{array}{l}\text { identification on maps, } \\
\text { diagrams, required } \\
\text { drawings or sketches, } \\
\text { read and response }\end{array}$ & $\begin{array}{l}\text { pair work, } \\
\text { group work }\end{array}$ & $\begin{array}{l}\text { reference maps, diagrams, } \\
\text { pictures }\end{array}$ \\
\hline Verbal & $\begin{array}{l}\text { summaries, } \\
\text { outlines, } \\
\text { debates }\end{array}$ & journaling, peer critiquing & summaries, outlines & group work & observation, reading \\
\hline Active & $\begin{array}{l}\text { class } \\
\text { participation }\end{array}$ & $\begin{array}{l}\text { model building, role } \\
\text { playing, presentations, } \\
\text { surveys/ opinion polls }\end{array}$ & projects, reports & group work & questionnaires \\
\hline Reflective & $\begin{array}{l}\text { class time for } \\
\text { reflection or } \\
\text { critical thinking }\end{array}$ & problem sets, journaling & problem solving & group work & observation, reading \\
\hline Sequential & $\begin{array}{l}\text { outlines, lists, } \\
\text { examples }\end{array}$ & $\begin{array}{l}\text { creation of steps, } \\
\text { processes, scanning }\end{array}$ & $\begin{array}{l}\text { creation or } \\
\text { reenactment of steps, } \\
\text { processes }\end{array}$ & $\begin{array}{l}\text { small } \\
\text { discussion } \\
\text { groups }\end{array}$ & $\begin{array}{l}\text { reference materials of a } \\
\text { procedural nature }\end{array}$ \\
\hline Global & $\begin{array}{l}\text { discussion of } \\
\text { concepts }\end{array}$ & $\begin{array}{l}\text { journaling, discussion, } \\
\text { relationship construction, } \\
\text { mapping, skimming }\end{array}$ & essay questions & $\begin{array}{l}\text { large } \\
\text { discussion } \\
\text { groups } \\
\end{array}$ & $\begin{array}{l}\text { broad based reference } \\
\text { materials, newspaper articles, } \\
\text { magazines and books }\end{array}$ \\
\hline
\end{tabular}

Principle 10: In assessing learners' target-language proficiency, it is important to examine free as well as controlled production.

Assessment should measure how proficiently learners can communicate. Our oral test sought to combine free and controlled production of language. The students were invited to choose a topic such as shopping and clothing to think and talk about. Talking about a topic is a guided or controlled speaking process. However, within the topic, the students could talk about that topic as freely as they could. After the free talk about the topic, the students would have to answer some questions posed by I - their teacher - built on the content of their talk. Nonetheless, students are not required to provide a particular "right answer". A communicative task that calls for a constructed response (with no single "right answer") is more like authentic communication and is therefore the best measure of learners' target-language proficiency.

\section{CONCLUding Thoughts}

Teaching is an interesting profession with new approaches expanding teachers' roles and giving teachers more insights into how to help their learners (Larsen-Freeman, 1988). A key to getting and keeping students effectively immersed in English language acquisition primarily lies in how Principles of Instructed Language Learning are effectively applied. Our reflection on teaching English through Principles of Instructed Language Learning is our way of continuous learning as Hyman and Rosoff (1987, p. 185) suggest teachers should also become students of teaching.

\section{REFERENCES}

[1] Brown, H.D. (2002). Principles of Language Learning and Teaching. New York: Longman.

[2] Brown, R. (1973). A first language: The early stages. Cambridge, Mass: Harvard University Press.

[3] Chomsky, N. (1965). Aspects of the theory of syntax. Cambridge, Mass: MIT Press.

[4] DeKeyser, R. (1998). "Beyond Focus on Form: Cognitive Perspectives on Learning and Practicing Second Language Grammar". In C. Doughty and J. Williams, ed. Focus on Form in Classroom Second Language Acquisition. Cambridge: Cambridge University Press.

[5] Dulay, H., Burt, M., and Krashen, S. (1982). Language Two. New York: OUP.

[6] Ellis, R. (2003). Task-based language learning and teaching. Oxford: Oxford University Press.

[7] Ellis, R. (2005). Principles of instructed language learning. System, 33 (2), 209-224.

[8] Hyman, R., \& Rosoff, B. (1987). Matching learning and teaching styles: The jug and what's in it. In Clarizio, Harvey F., Robert C. Craig, \& William A. Mehrens (Eds.), Contemporary Issues in Educational Psychology. New York: Random House.

[9] Jones, L. (2008). Let's Talk 1 ( $2^{\text {nd }}$ ed). New York, NY: Cambridge University Press.

[10] Krashen, S.D. (1981). Bilingual education and second language acquisition theory. In Bilingual Education Office (Ed.), Schooling and language-minority students: A theoretical framework (pp. 51-79). Los Angeles: Evaluation, Dissemination, and Assessment Center.

[11] Larsen-Freeman, D. (1998). Expanding roles of learners and teachers in learner-centered instruction. In Renandya, W. A. \& Jacobs, G. M. (Eds.), Learners and Language Learning (pp. 207-226). Anthology Series 39. Singapore: Seameo Regional Language Centre. 
[12] Long, M. (1991). "Focus on Form: A Design Feature in Language Teaching Methodology". In K. de Bot, R. Ginsberg and C. Kramsch, ed, Foreign Language Research in Cross-cultural Perspective. Amsterdam: John Benjamin, pp. 39-52.

[13] Renandya, W.A., Lim, W.L., Leong, K.W., and Jacobs, G.M. (2001, January). A survey of English language teaching trends and practices in Southeast Asia [Lecture Notes]. Singapore: SEAMEO Regional Language Centre.

[14] Sarasin, L.C. (1999). Learning styles: Impact in the classroom. Madison, Wisc: Atwood.

[15] Schumann, J.H. (1978). The Pidgination Process: A Model for Second Language Acquisition. Rowley, MA: Newbury House.

Luu Hoang Mai is an English teacher at Saigon Technology University (STU) and University of Social Sciences \& Humanities, Ho Chi Minh City. She earned her BA degree from University of Social Sciences \& Humanities, Ho Chi Minh City. Her research interests encompass language acquisition, task-based language teaching, and learning strategies.

Luu Thi Bich Ngoc is a teacher at Open University, Ho Chi Minh City. Her research interests cover educational leadership and classroom management.

Luu Trong Tuan is a teacher at University of Finance-Marketing, Ho Chi Minh City. His publication portfolio indicates his research in learning styles and translation strategies. 